Review

\title{
Enhancing Wave Energy Competitiveness through Co-Located Wind and Wave Energy Farms. A Review on the Shadow Effect
}

\section{Sharay Astariz ${ }^{1, *}$ and Gregorio Iglesias ${ }^{2}$}

1 Department of Hydraulic Engineering, EPS, University of Santiago de Compostela, Campus Universitario s/n, Lugo 27002, Spain

2 School of Marine Science and Engineering, University of Plymouth, Drake Circus, Plymouth PL4 8AA, UK; E-Mail: gregorio.iglesias@plymouth.ac.uk

* Author to whom correspondence should be addressed; E-Mail: sharay.astariz@usc.es; Tel.: +34-982-823-295; Fax: +34-982-285-926.

Academic Editor: John Ringwood

Received: 30 April 2015 / Accepted: 13 July 2015 / Published: 21 July 2015

\begin{abstract}
Wave energy is one of the most promising alternatives to fossil fuels due to the enormous available resource; however, its development may be slowed as it is often regarded as uneconomical. The largest cost reductions are expected to be obtained through economies of scale and technological progress. In this sense, the incorporation of wave energy systems into offshore wind energy farms is an opportunity to foster the development of wave energy. The synergies between both renewables can be realised through these co-located energy farms and, thus, some challenges of offshore wind energy can be met. Among them, this paper focuses on the longer non-operational periods of offshore wind turbines - relative to their onshore counterparts - typically caused by delays in maintenance due to the harsh marine conditions. Co-located wave energy converters would act as a barrier extracting energy from the waves and resulting in a shielding effect over the wind farm. On this basis, the aim of this paper is to analyse wave energy economics in a holistic way, as well as the synergies between wave and offshore wind energy, focusing on the shadow effect and the associated increase in the accessibility to the wind turbines.
\end{abstract}

Keywords: wave energy; offshore wind energy; co-located wind-wave farm; synergies; cost reductions; weather windows for $\mathrm{O} \& \mathrm{M}$ 


\section{Introduction}

Ocean energy has emerged with force in the search for alternatives to conventional energy resources. Nevertheless, there are some barriers that may hinder the development of marine energies, such as the early stage of development of the technologies [1-11], high costs involved [12-16] or uncertainties regarding the environmental impacts [17-27]. Among the different alternatives of ocean energy, this work focuses on two of them: Offshore wind and wave energy. As for the former, investment in offshore wind systems has been growing rapidly throughout Europe in order to achieve EU targets for renewable energy in 2020 [28], due to the powerful available resource [29-32] and its similarities to its onshore counterpart. However, there exist some limitations that could hinder its introduction into the energy mix, such as the higher investment implied, more demanding maintenance tasks or power variability. For its part, wave energy presents extensive possibilities for the future thanks to its enormous potential for electricity production [12,15,33-39]. In fact, the global wave energy potential resource has been estimated at $10 \mathrm{TW}$ [22], and depending on what is considered to be exploitable, this covers from $15 \%$ to $66 \%$ of the total world energy consumption [40,41]. Its technology is in its infancy, despite recent research on Wave Energy Converters (WECs) [42-45] and its structural response [46-48], and it presents higher levelised costs than any non-renewable energy and also than most renewables [49]. Therefore, at present, wave energy is only economically viable if subsidized. However, over time important cost reductions can be expected to occur through economies of scale and technological effects, such as technological advances and improvements by practice.

In this sense, combining wave energy systems with offshore wind farms has been regarded as a good solution to promote and accelerate the development of wave energy technology [50-52]; at the same time a better use of the marine resource would be achieved [53] and the installation and operation costs would be reduced by sharing common installations [53]. Besides, other synergies arise when this combination is considered, such as a better predictability of the energetic resource [49], smoothed power output [54] or enlarged weather windows for operation and maintenance tasks [55]. The latter is of special interest for this paper: The energy extraction of an array of WECs creates a wake that modifies the local wave climate by reducing the mean wave height, which is known as the shadow effect [56].

On this basis, the first aim of this study is to offer a review of wave energy economics, comparing this renewable with other conventional energy sources and assessing the influence on the conclusions about wave energy profitability of including other factors like the learning curve or externalities. Second, combined wave and wind systems are proposed as a way to reduce costs and boost the joint development of both renewables taking advantage of the mutual benefits of their combination. In this line, the existing synergies between wave and offshore wind energy systems are analysed in this paper, paying special attention to the shielding effect of co-located WECs, which leads to enlarged weather windows for Operation and Maintenance $(\mathrm{O} \& \mathrm{M})$ tasks, thereby reducing the non-operational periods of wind turbines due to delays in maintenance tasks - one of the challenges of this renewable, not least when it is compared with onshore wind. The analysis of the so-called shadow effect is based on the results of previous studies, which allow the assessment of the influence of the wind farm characteristics and the co-located WECs layout on the benefit achieved-which are translated into monetary terms. 


\section{Economics of Wave Energy}

Among the different options of wave energy farms (onshore, nearshore and offshore), this paper focuses on offshore wave energy farms since this is closer than any other to commercial development [40,57]. The main costs in a wave energy plant are the following: (i) pre-operating cost; (ii) capital expenditure (CAPEX); (iii) operational expenditure (OPEX); and (iv) decommissioning costs. As Figure 1 shows, the pre-operating and decommissioning costs are insignificant in the total, whereas $\mathrm{O} \& \mathrm{M}$ (plus the replacement) represents $64.99 \%$ of the total, and the initial investment $34.68 \%$ [58].

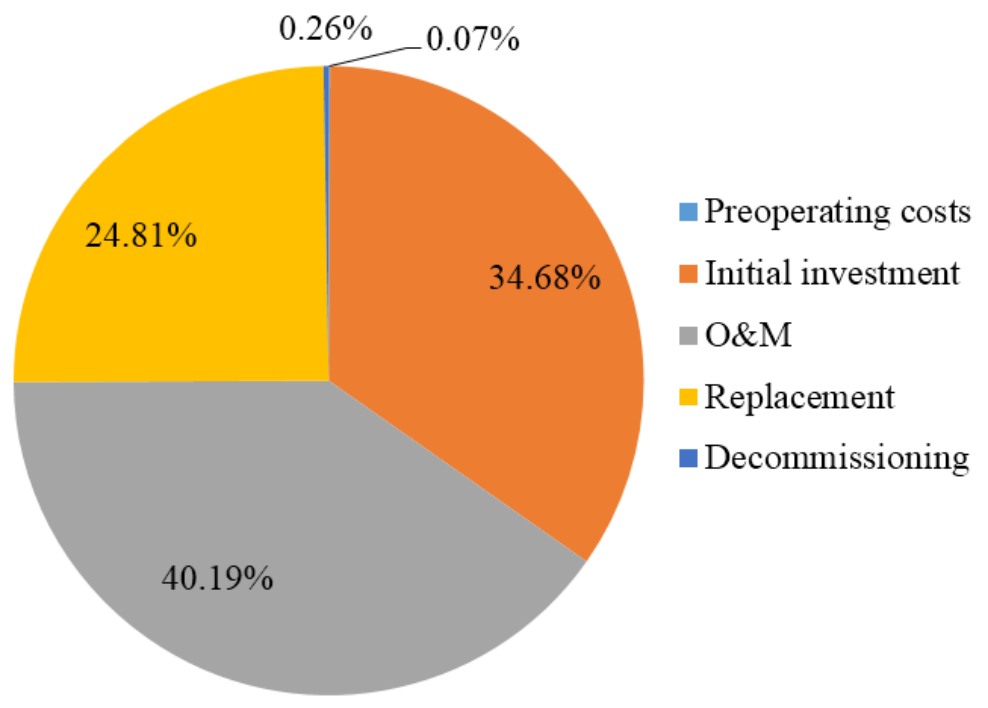

Figure 1. Percentage of each individual cost in the levelised cost.

As for the former, the pre-operating cost involves all the expenses incurred on preliminary studies, projects, environmental impact assessment, consenting procedures, etc., as well as direction and coordination. It will depend on a number of factors, such as the location, as policies vary from one country to other, or the size of the installation. Because of that, there is a wide range of values for this cost reported in the bibliography, and it is usually expressed as a percentage of the capital costs (Table 1).

Table 1. Pre-operating and licenses costs.

\begin{tabular}{ccc}
\hline Category & Cost & Source \\
\hline \multirow{2}{*}{ Pre-operating cost } & $10 \%$ CAPEX $(€)$ & {$[14,59]$} \\
& $500,000-2,000,000 €$ & {$[60]$} \\
\hline \multirow{2}{*}{ Licenses and permissions } & $0.037 \times$ Installed Power in W $(\$)$ & {$[61]$} \\
& $2 \%$ WECs cost $(€)$ & {$[14,59]$} \\
\hline
\end{tabular}

For its part, the capital expenditure (CAPEX) includes the costs of the WECs and other elements of the wave energy plant, as well as their installation (Table 2). There is little available information about the cost of wave energy technology due to its initial stage of development. Table 3 shows the cost of three WECs that are close to a commercial stage. If the installation is included, the total cost rises to 2.5-6.0 M€ per installed MW [62-64]. 
Table 2. Summary of initial costs.

\begin{tabular}{ccc}
\hline Element & Cost & Source \\
\hline WEC and installation & $2.5-6.0 \mathrm{M} € / \mathrm{MW}$ & {$[62-64]$} \\
& $10 \% \mathrm{WECs}$ cost & {$[12,59,65,66]$} \\
Mooring system & $0.265 € / \mathrm{N}$ & \\
& $50,000 € /$ day & {$[67]$} \\
Mooring Installation & $10 \% \mathrm{CAPEX}$ & {$[14,68]$} \\
Underwater cable & $2.07 € / \mathrm{m}$ & {$[69]$} \\
Cable installation & $\approx 1.2 \mathrm{M} €$ & {$[70]$} \\
Electrical substation & & \\
\hline
\end{tabular}

Table 3. Rated power and estimated cost of WaveDragon, Pelamis and AquabuOY (sources: [71-74]).

\begin{tabular}{cccc}
\hline Technology & WaveDragon & Pelamis & AquabuOY \\
\hline Rated power $(\mathrm{kW})$ & 7000 & 750 & 250 \\
Cost $(\$ /$ unit $)$ & $16,800,000$ & $25,000,000$ & 200,000 \\
\hline
\end{tabular}

Both with the initial investment, the operation and maintenance cost (OPEX) has an important weight in the total cost of the installation throughout its lifetime. Since there is not enough experience in wave energy installations, a preliminary estimation of this expenditure can be made on the basis of the experience in the oil and gas and offshore wind energy sectors (Table 4). Moreover, the whole plant is supposed to be dismantled after 20 years and the decommissioning cost is estimated to be $0.5 \%-1 \%$ of the initial investment [60].

Table 4. Annual costs of operation and maintenance (source: [49]).

\begin{tabular}{cccc}
\hline Cost & $\boldsymbol{\epsilon} / \mathbf{M W h}$ & \% CAPEX & \%OPEX \\
\hline O \& M tasks & $20-35$ & $1.5 \%-5 \%$ & $57 \%$ \\
Revision and time off & & 10 & \\
Spares & & 90 & \\
Public services & 3.5 & & \\
Renting & & 2.5 & \\
Insurance cost & 15 & $0.8 \%-2 \%$ & $13 \%-14 \%$ \\
\hline
\end{tabular}

All in all, the levelised cost of wave energy - which is the ratio of total lifetime expenses vs. total expected outputs expressed in terms of the present value [12] — ranges between $180 € / \mathrm{MWh}$ and $490 € / \mathrm{MWh}$ [49]. These values are quite higher than those of other traditional non-renewable electricity generation methods like pulverized fuel or even more recent methods like combined cycle gas turbine with carbon capture and storage, whose costs are respectively $32.57 € / \mathrm{MWh}$ and $59.78 € / \mathrm{MWh}$ [49]. Moreover, wave energy is also more expensive than consolidated renewables like onshore wind energy (67.68 $€ / \mathrm{MWh})$ and even than other emerging renewables like offshore wind energy (101.43 €/MWh). Therefore, wave energy seems not to be economically competitive in the present days. However, cost reductions are expected to be increased through economies of scale and technological effects, such as technological advances and improvements by practice, which are reflected by the learning curve (Equation (1)). In this line, there are not many studies examining the impact of learning curves on the profitability of wave energy plants. Despite that, most of them agree on a 
learning rate of $85 \%-90 \%$ within the next 10 years [14,75-78]. If this is considered, even in a pessimistic scenario characterised by slow development of wave technology, low installed capacity and, consequently, small learning factor, a reduction in the levelised cost of wave energy around 22\% may be obtained [58].

$$
\frac{C_{x}}{C_{0}}=\left(\frac{P_{x}}{P_{0}}\right)^{\left(\frac{\log f}{\log 2}\right)}
$$

where $C_{x}$ is the costs at time $x, C_{0}$ is the costs at time $0, P_{x}$ is the cumulated capacity at time $x, P_{0}$ is the cumulated capacity at time 0 and $f$ is the learning factor. Furthermore, decisions about energetic planning are usually based on the generation cost of each source of energy, forgetting the other stages in energy production. Nevertheless, as with all human activities, energy production has impacts (positive and negative), which must be considered in the total energy cost. This is known as externalities. A new tendency has emerged to assess the energy cost which consists on internalizing these externalities [58]. For that purpose, the first step is to determine the impacts (positive and negative) which have to be considered in the energy production process taking into account entire the life cycle. One of the procedures followed to evaluate physical impacts is the Impact Pathway Approach of ExternE [79,80], which identifies: (i) emission sources; (ii) dispersion (increase in ambient concentration); (iii) impacts; and (iv) associated cost. For example, it is estimated that carbon emissions in wave energy are $6 \mathrm{gCO}_{2} / \mathrm{kWh}$ [81], whereas the average value for conventional energy sources is around $250 \mathrm{gCO}_{2} / \mathrm{kWh}$ [82]. Therefore, a reduction of $244 \mathrm{gCO}_{2} / \mathrm{kWh}$ would be achieved by wave energy production, and this should be included in the energy price. Additionally, the environmental externalities there are others that should be considered, such as the creation of new jobs or the increase of the supply security, reducing the risk of supply cuts of conventional fuels, and therefore avoiding important economic losses; e.g., a cut of one day in the gas supply in Spain would produce a loss of $0.03 \%$ of the GDP [83]. All in all, oil and coal technologies for electricity production have associated high external costs (60 and $58 € / \mathrm{MWh}$, respectively) in comparison with other non-renewables like natural gas $(15 € / \mathrm{MWh})$, and the difference is still greater in the case of wind energy, with an external cost of a mere $1.75 € / \mathrm{MWh}$ [84-86]. In fact, a study [58] concluded that if the externalities were included in the economic studies analysing which technology is most viable, the conclusions would change substantially (Figure 2).

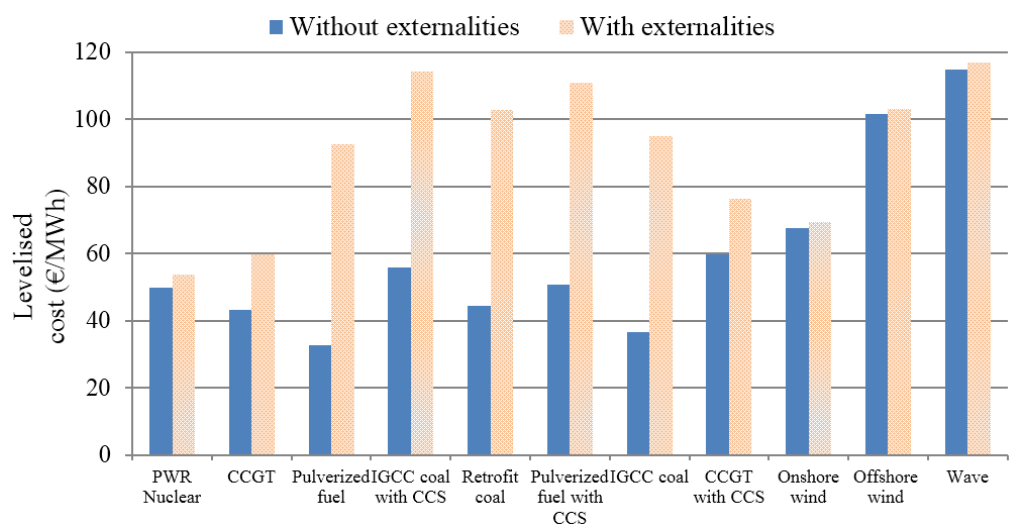

Figure 2. Levelised cost $(€ / M W h)$ of different technologies including external costs. (Reprinted with permission from [58]. Copyright 2015 Taylor \& Francis) 


\section{Co-Located Wind and Wave Energy Farms}

Taking advantage of various renewable resources simultaneity is being regarded as an opportunity to turn renewables into a more cost-competitive option. In the case of wave energy, the combination with offshore wind energy is emerging with force due to the existing synergies between both renewables. According to the global distribution of the wind and wave energy resources (Figure 3), it is apparent that there are some areas with large possibilities to these combined options.

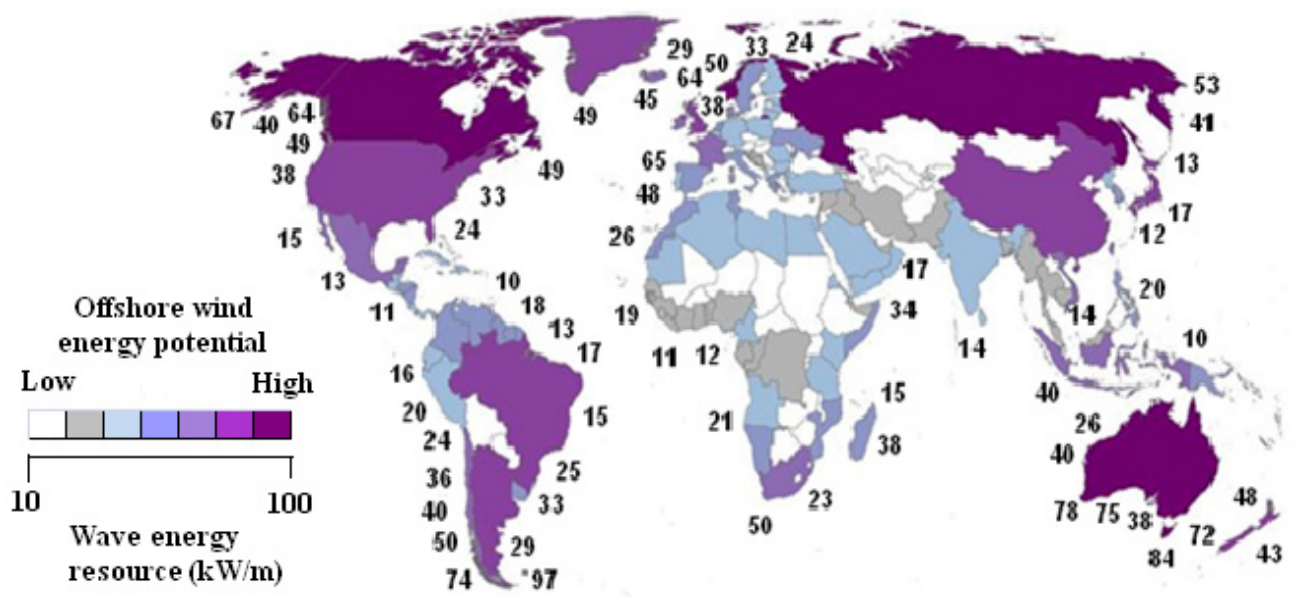

Figure 3. Global distribution of offshore wind and wave energy resources. The former is reflected through the colour scale and the latter by means of the energy density $\left(\mathrm{kWm}^{-1}\right)$ : $10 \mathrm{kWm}^{-1}$ is the minimum needed for a commercial scale wave energy project.

There are different possibilities for a combined wave and wind array [53]: (i) co-located wind-wave energy; (ii) hybrid converters; and (iii) energy islands (Figure 4). This work focuses on the former, co-located systems $[87,88]$, since they are the simplest option at the present stage of development of wave and offshore wind technologies $[30,89,90]$. These systems combine an offshore wind farm with a WEC array with independent foundation systems but sharing: The same marine area, grid connection, $\mathrm{O} \& \mathrm{M}$ equipment and personnel, port structures, etc. [51].
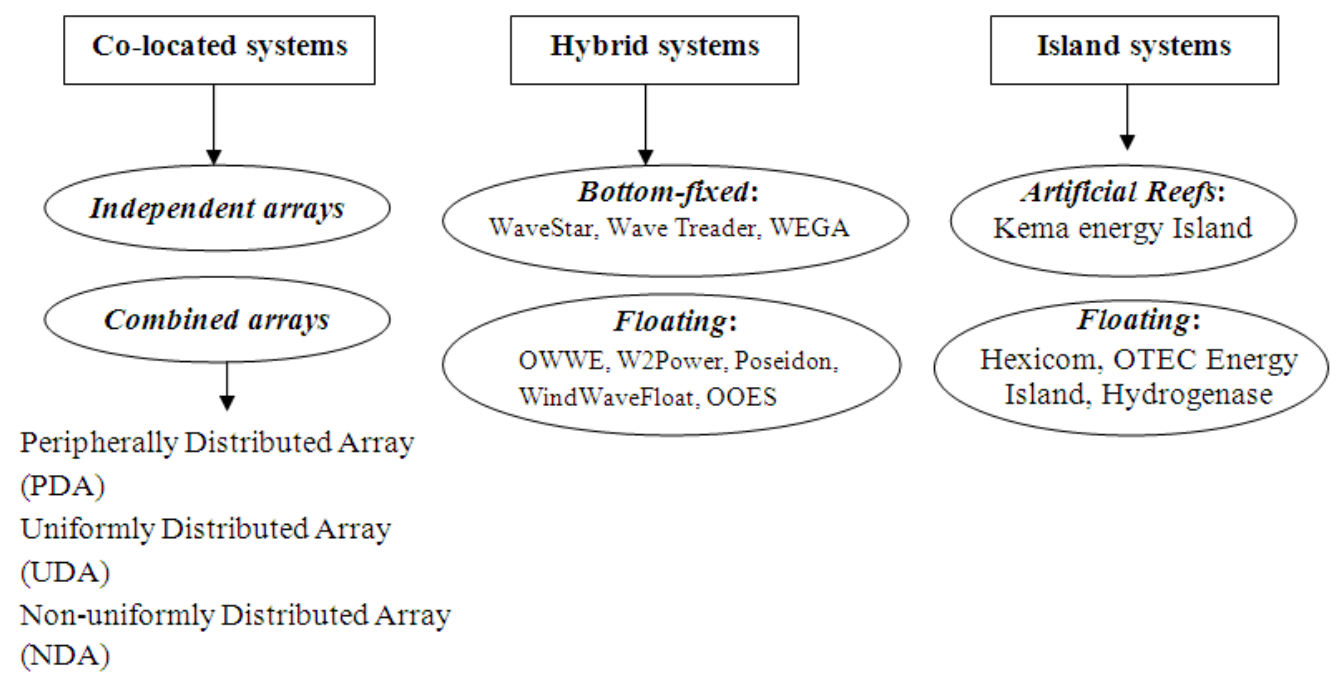

Figure 4. Classification of combined wave-wind technologies. 
There are many synergies that could be exploitable to overcome some of the barriers that marine energies could present to entry into the market. First of all, important cost savings could be achieved during the setup of the energy farms because of common elements and coordinated strategies [54,91-93]. The largest savings would be achieved in the electrical connection, since the offshore station and the export cable can be the same for both installations. When hybrid technology was developed, important cost reductions in the substructure foundation system would be achieved as hybrid wave converter systems share the same substructure or foundation with the offshore wind turbine [89,91]. Moreover, the cost of $\mathrm{O} \& \mathrm{M}$ tasks can be reduced in co-located farms since the scheduled maintenance of wave and wind energy can be organised to be done at the same time or in continuous length of time [53]. A recent study [94] achieved cost savings around $25 \%$ in the capital costs and up to $14 \%$ in the maintenance costs of combined wave and wind energy farms. Moreover, offshore developers pay for leases according to the area occupied, so covering the same area with two sources of electricity generation reduces these costs.

Besides, the combination of two different technologies harnessing different sources of energy at a single array site will increase the global energy yield per array unit and thereby contribute to a more sustainable use of the natural resources [53]. In this sense, combined energy farms would reduce the feasible environmental impact of these offshore energy installations since the affected area will be smaller than in the case of wave and wind farms as separate installations. Furthermore, recent studies have concluded that introducing WECs in offshore wind energy parks compensates the power variability and, thus, smoothes the power output [87,95-97]. This way, balancing cost could be reduced up to $35 \%$ [98]. Moreover, a recent work [99] found that waves and the power output of WECs are $23 \%$ and $35 \%$, respectively, more predictable than winds and the wind turbine power output. Finally, wave energy developers can eliminate part of the financial risk in this unproven technology by coordinating with wind projects. As a consequence, the learning curve effect would lead to faster reductions in the cost of wave energy, enhancing its competitiveness.

\section{Enlarged Weather Windows}

In addition to the above benefits, other technological synergies would be realised through combined wave and wind energy farms, such as the so-called shadow effect. The operational limit of workboats for $\mathrm{O} \& \mathrm{M}$ tasks - the most cost-effective access system-is a significant wave height of $1.5 \mathrm{~m}[100,101]$. When this threshold is exceeded delays in maintenance and repairs ensue, and the resulting downtime causes earnings to be missed. Co-located WECs deployed at the periphery of the wind farm could produce a shielding effect over the offshore wind farm that enlarges the weather windows for $\mathrm{O} \& \mathrm{M}$. This increase in the accessibility to the wind turbines brings in reduced downtime and, thus, in considerable cost savings - around $25 \%$ of the $\mathrm{O} \& \mathrm{M}$ costs that would lead to an reduction in the overall project cost of energy of 2.3 percent [102]. The analysis of the shadow effect provided by co-located WECs at the periphery of a wind farm was investigated in previous studies $[55,103,104]$ through four real wind farms currently in operation, whose locations and characteristics are presented in Figure 5 and Table 5, respectively. Comparing this information, it can be stated that these four wind farms encompass a wide variety of characteristics on which to establish a comparative analysis. The third-generation numerical wave model SWAN (Simulating WAves 
Nearshore) was used to simulate wave propagation. In all simulations, high-resolution results were obtained as the model was implemented by grids with resolution higher than $40 \mathrm{~m}$. Both WECs and wind turbines were represented in the model by a transmission coefficient, whose value can vary from $0 \%$ (i.e., $100 \%$ of incident wave energy absorbed) to $100 \%[17,18,20,27,30,105-108]$.

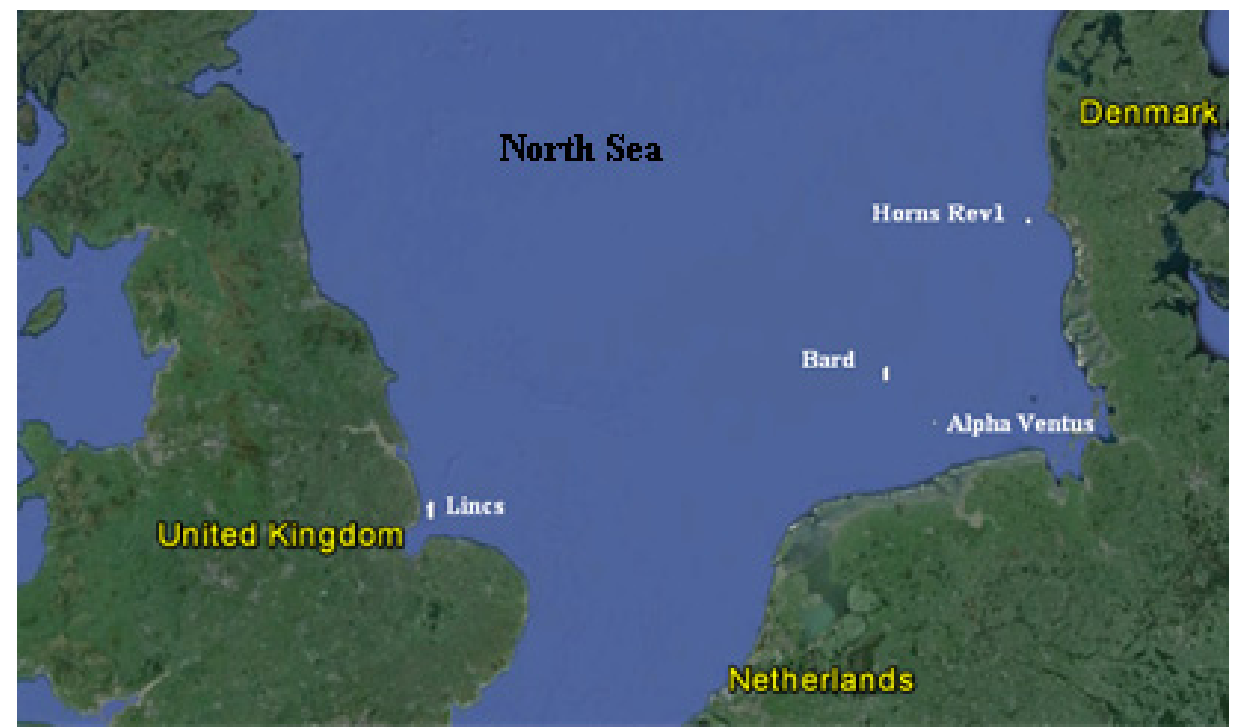

Figure 5. Location of the four wind farms: Alpha Ventus, Bard 1, Horns Rev 1 and Lincs. (Reprinted with permission from [103]. Copyright 2015 Elsevier Science Ltd.).

Table 5. Characteristics of the offshore wind farms. (Reprinted with permission from [103]. Copyright 2015 Elsevier Science Ltd.)

\begin{tabular}{cccccc}
\hline Wind Farm & Depth (m) & $\begin{array}{c}\text { Distance from } \\
\text { Shore }(\mathbf{k m})\end{array}$ & $\begin{array}{c}\text { Installed } \\
\text { Capacity (MW) }\end{array}$ & $\begin{array}{c}\text { Number } \\
\text { Turbines }\end{array}$ & Area (km $\left.\mathbf{k}^{\mathbf{2}}\right)$ \\
\hline Alpha Ventus & $33-45$ & 56 & 60 & 12 & 4 \\
Bard 1 & $39-41$ & $90-101$ & 400 & 80 & 59 \\
Horns Rev 1 & $6-14$ & $14-20$ & 160 & 80 & 21 \\
Lincs & $8-16$ & 8 & 270 & 75 & 41 \\
\hline
\end{tabular}

With regard to the wind farm layout (Figure 6), the Alpha Ventus wind farm is composed by 12 turbines: six AREVA turbines with a tripod substructure and six Repower $5 \mathrm{M}$ turbines with a jacket-frame substructure [109]. For their part, Bard 1 has 80 wind turbines of $5 \mathrm{MW}$ (Bard 5.0) and a tripod substructure [110-112], Horns Rev 1 has 80 turbines (Vestas V80-2MW) with a monopile substructure erected on a grid of 10 rows [113] and Lincs is composed of 75 wind turbines Siemens 3.6 MW with monopile substructure [114,115]. At Alpha Ventus and Horns Rev 1 the wind turbines are ordered on a Cartesian grid, whereas in Bard 1 and Lincs they are not organised in clearly defined rows, and the distance between turbines varies in each case.

The wind farms selected as baseline scenarios presented levels of accessibility to the wind turbines - percentage of time when the significant weight height within the wind farm is under the workboat limit, $1.5 \mathrm{~m}$ - between $57 \%$ and $74 \%$ during the study period (Table 6), whereas a level of accessibility around $82 \%$ is required to ensure an availability - the percentage of time that the farm is able to produce electricity - of $90 \%$ [116]. This is in well concordance with the general panorama, 
since while modern onshore wind turbines show availability levels of $98 \%$ [117], this level is significantly reduced in offshore installations [117-120].
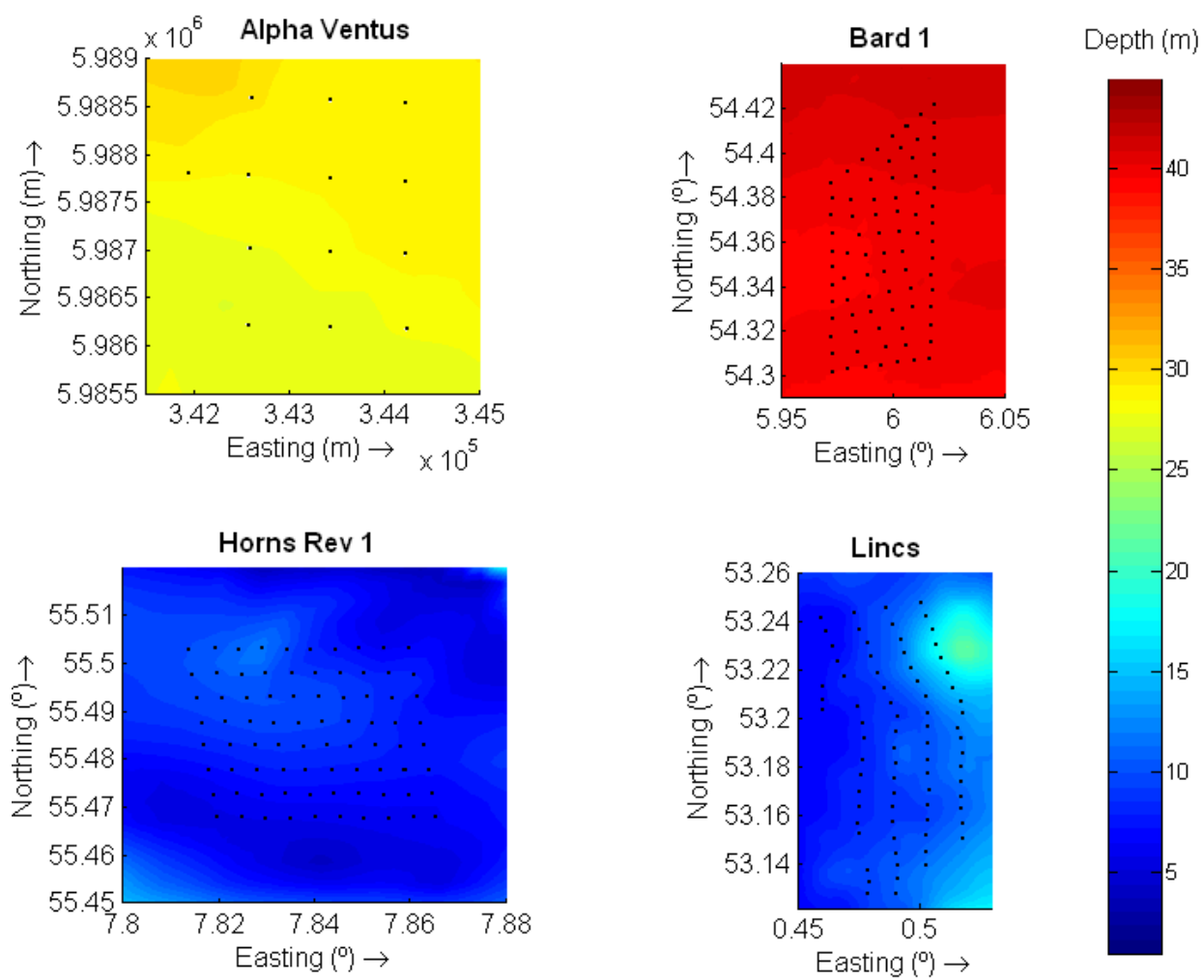

Figure 6. Layout and bathymetry of Alpha Ventus, Bard 1, Horns Rev 1 and Lincs (water depths in m). (Reprinted with permission from [103]. Copyright 2015 Elsevier Science Ltd.)

Table 6. Accessibility to the wind turbines in the baseline scenario for the annual period analysed. (Reprinted with permission from [103]. Copyright 2015 Elsevier Science Ltd.)

\begin{tabular}{cc}
\hline Wind Farm & Accessibility (\%) \\
\hline Alpha Ventus & 67.53 \\
Bard 1 & 56.99 \\
Horns Rev 1 & 59.86 \\
Lincs & 74.11 \\
\hline
\end{tabular}

In the light of this situation, a wide variety of co-located wave farm layouts were analysed in Alpha Ventus (Table 7, Figure 7) in order to identify the configurations that maximise the wave height reduction. They are characterised by different spacing between WECs, disposition and number of devices, with the aim of providing shelter not only from NW waves (the prevailing wave direction) but also from $\mathrm{W}$ and $\mathrm{SW}$ waves, which are relatively frequent in the area. In all cases, WaveCat, a floating

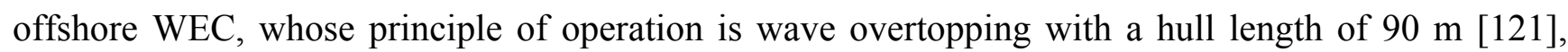
was the WEC employed. The simulations were carried out considering the predominant sea state in the Alpha Ventus site: $H_{s}=1.5 \mathrm{~m}, T_{p}=6.5 \mathrm{~m}$ and $\theta=330^{\circ}$. 
Table 7. Characteristics of the WEC layouts, with nWECS $_{\text {the }}$ total number of WECs. (Reprinted with permission from [55]. Copyright 2015 Elsevier Science Ltd.)

\begin{tabular}{|c|c|c|c|c|}
\hline No. & Spacing (m) & Configuration & $n_{W E C s}$ & Short Description \\
\hline 1 & & $A_{i}$ & 9 & 2 rows to the NW. \\
\hline 2 & 750 & $\mathrm{~A}_{\mathrm{ii}}$ & 12 & 2 rows to the NW and 2 more rows to the $\mathrm{W}$, at an angle of $45^{\circ}$. \\
\hline 3 & & $\mathrm{~A}_{\mathrm{iii}}$ & 12 & Arch to the NW. \\
\hline 4 & & $\mathrm{~B}_{\mathrm{i}}$ & 12 & 2 rows to the NW. \\
\hline 5 & 450 & $\mathrm{~B}_{\mathrm{ii}}$ & 17 & 2 rows to the NW and 2 more rows to the $\mathrm{W}$, at an angle of $45^{\circ}$. \\
\hline 6 & & $\mathrm{~B}_{\mathrm{iii}}$ & 17 & Arch to the NW. \\
\hline 7 & & $\mathrm{C}_{\mathrm{i}}$ & 22 & 2 rows to the NW \\
\hline 8 & 198 & $\mathrm{C}_{\mathrm{ii}}$ & 30 & 2 rows to the $\mathrm{NW}$ and 2 more rows to the $\mathrm{W}$. \\
\hline 9 & & $\mathrm{C}_{\mathrm{iii}}$ & 28 & Arch to the NW. \\
\hline 10 & & $\mathrm{C}_{\mathrm{ib}}$ & 27 & $\begin{array}{l}2 \text { rows to the NW and } 1 \text { row to the SW of the farm constituted } \\
\text { by } 5 \text { additional WECs. }\end{array}$ \\
\hline 11 & & $\mathrm{C}_{\mathrm{ic}}$ & 31 & $\begin{array}{l}2 \text { rows to the NW and } 2 \text { more rows to the SW of the farm } \\
\text { constituted by } 9 \text { additional WECs. }\end{array}$ \\
\hline 12 & 198 & $\mathrm{C}_{\mathrm{iib}}$ & 32 & $\begin{array}{l}2 \text { rows to the NW and } 2 \text { more rows to the } \mathrm{W} \text {, at an angle of } 45^{\circ} \text {. } \\
\text { ( } 2 \text { additional WECs) }\end{array}$ \\
\hline 13 & & $\mathrm{C}_{\mathrm{iic}}$ & 34 & $\begin{array}{l}2 \text { rows to the NW and } 2 \text { more rows to the } \mathrm{W} \text {, at an angle of } 45^{\circ} \text {. } \\
\text { (4 additional WECs) }\end{array}$ \\
\hline 14 & & $\mathrm{C}_{\mathrm{iiib}}$ & 30 & Arch to the NW with 2 additional WECs. \\
\hline 15 & & $\mathrm{C}_{\mathrm{iiic}}$ & 32 & Arch to the NW with 4 additional WECs. \\
\hline
\end{tabular}
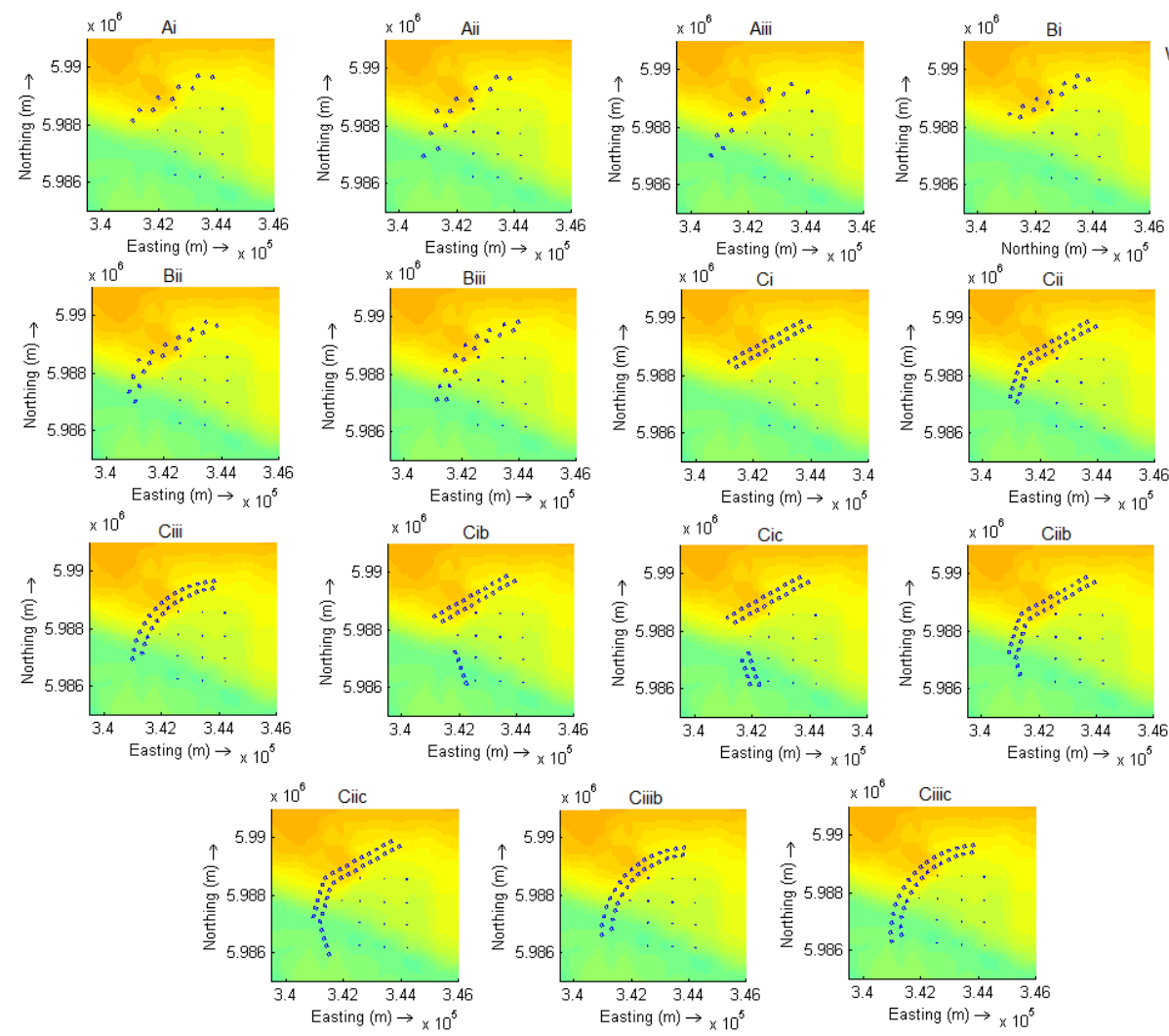

Figure 7. Co-located wave-wind farm layouts (configurations $A_{i}$ to $\mathrm{C}_{\mathrm{iiic}}$ ). (Reprinted with permission from [55]. Copyright 2015 Elsevier Science Ltd.) 
In view of the results, the highest wave height reductions were obtained in the configurations with low spacing between devices, not only due to the larger number of WECs but also by the aggregation of the shadow effect provided by each devices, reaching average wave height reductions up to $24.91 \%$ in the whole farm. Among these layouts, $\mathrm{C}_{\mathrm{i}}, \mathrm{C}_{\mathrm{ib}}$ and $\mathrm{C}_{\mathrm{ic}}$ should be rejected since they leave part of the wind farm unprotected (Figure 8). Therefore, the best WECs layouts were $\mathrm{C}_{\mathrm{iic}}$ and $\mathrm{C}_{\mathrm{iiic}}$ which corresponds with: Two main rows of WECs with a spacing of $198 \mathrm{~m}$ orientated towards the prevailing wave direction and other two rows of devices to face secondary waves deployed in an angular configuration in the first case and forming an arch in the latter.
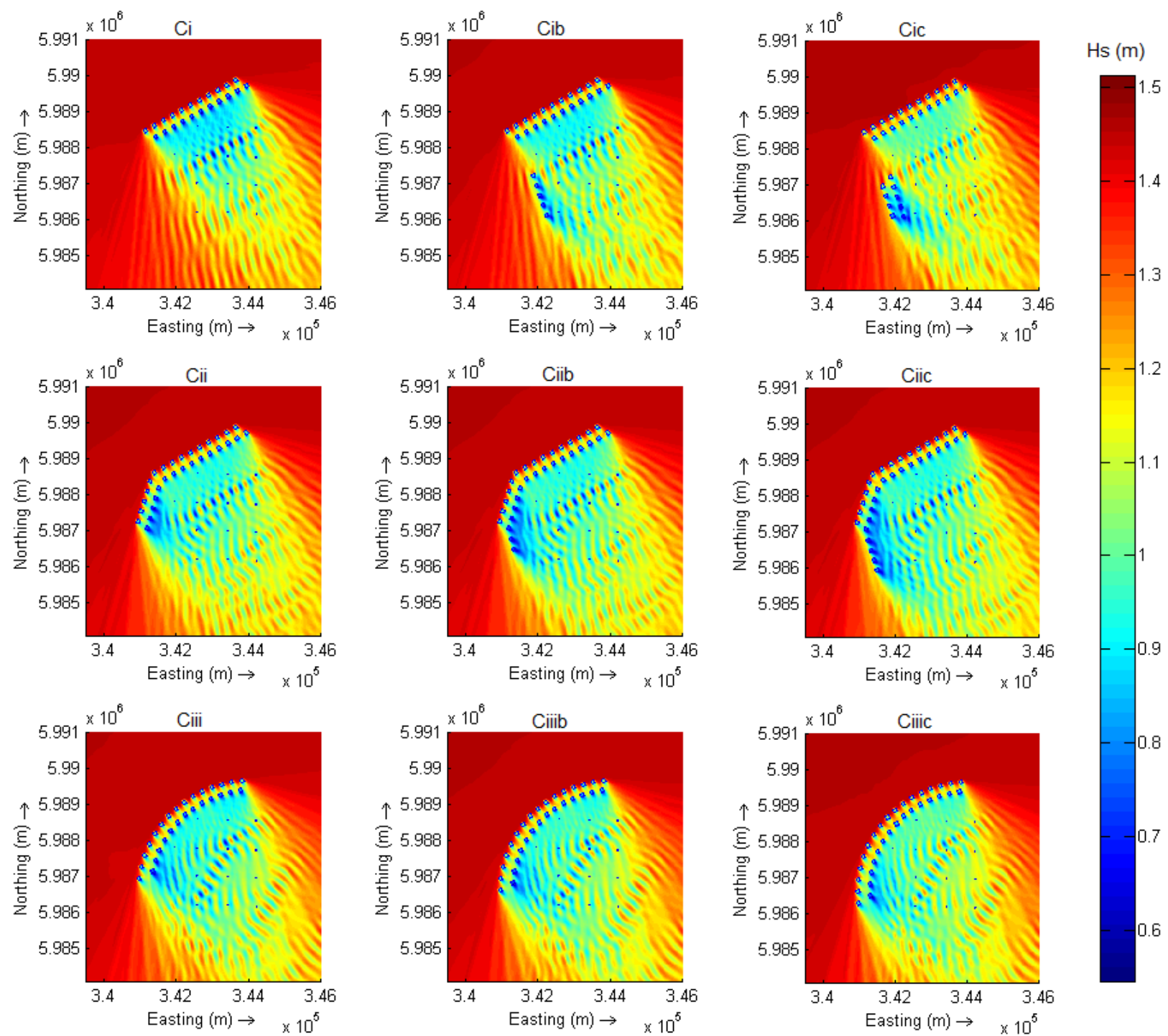

Figure 8. Wave height reduction within the Alpha Ventus wind farm for the predominant sea state in this site: $H_{s}=1.5 \mathrm{~m}, T_{p}=6.5 \mathrm{~m}$ and $\theta=330^{\circ}$ and configurations $\mathrm{C}_{\mathrm{i}}$ to $\mathrm{C}_{\mathrm{iiic}}$. (Reprinted with permission from [55]. Copyright 2015 Elsevier Science Ltd.)

On this basis, these both configurations (Figures 9 and 10) were analysed in depth in the four wind farms - Alpha Ventus, Bard 1, Horns Rev 1 and Lincs - by considering annual measured wave data during 2012 and 2013 by buoys located in the vicinities of the wind farms [103]. The number of WECs and the rate with the number of wind turbines is shown in Table 8. 

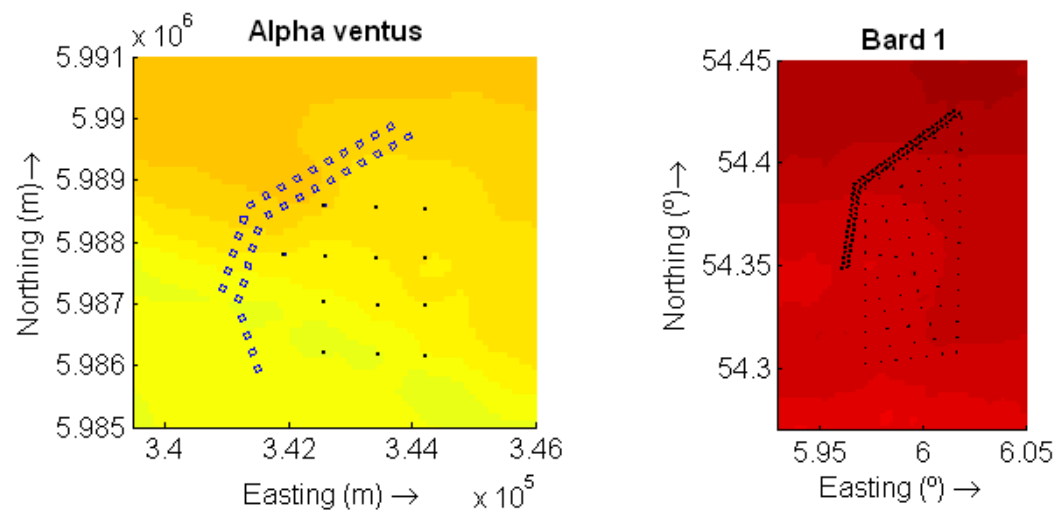

Depth (m)
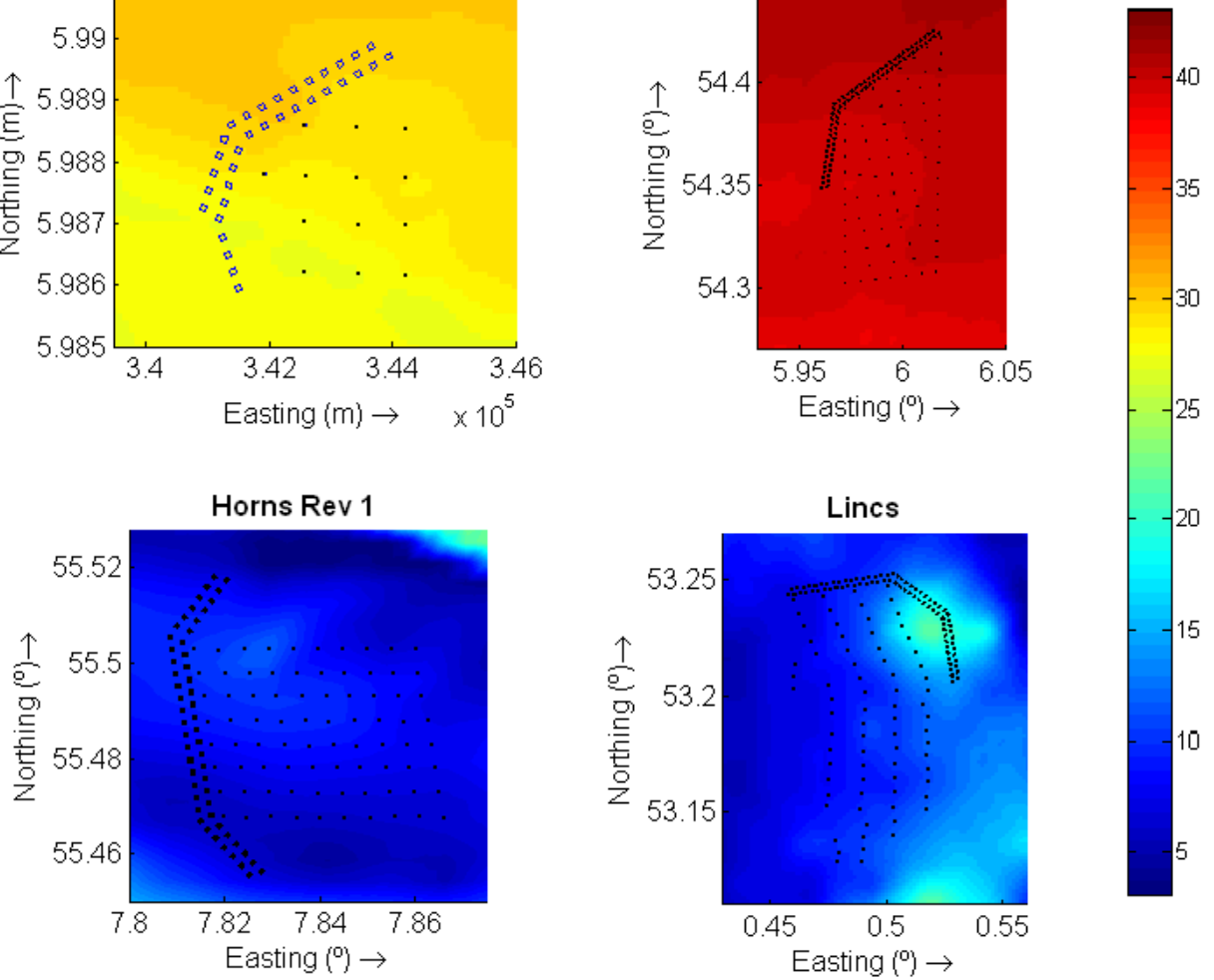

Figure 9. Co-located wind farm layouts with WECs at an angle. (Reprinted with permission from [103]. Copyright 2015 Elsevier Science Ltd.)
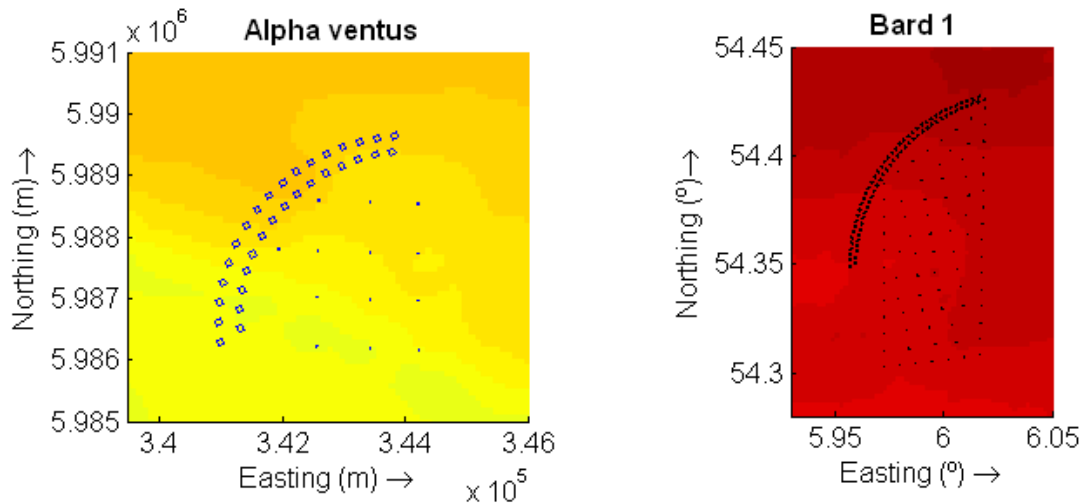

Depth (m)
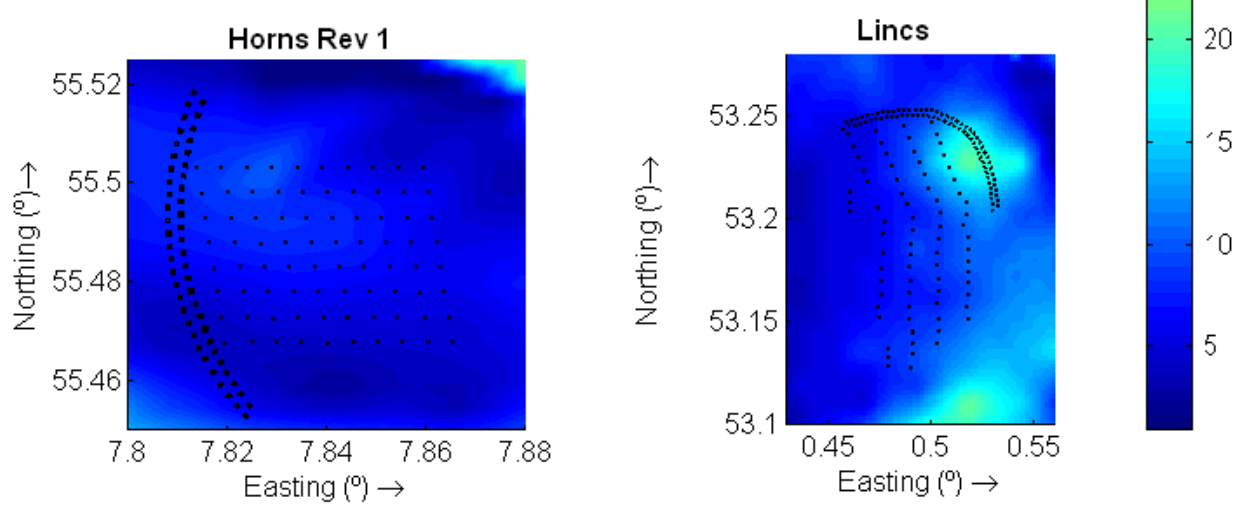

Figure 10. Co-located wind farms with an arched WEC layout. (Reprinted with permission from [103]. Copyright 2015 Elsevier Science Ltd.) 
Table 8. Total number of co-located WECs, number of devices in each $i$-th Vertical Row $(V R i)$ of co-located WECs and rate between the total number of WECs and wind turbines $(r)$.

\begin{tabular}{|c|c|c|c|c|c|c|c|c|}
\hline \multirow{2}{*}{ Wind Farm } & \multicolumn{4}{|c|}{ Layout in Angle } & \multicolumn{4}{|c|}{ Layout in Arch } \\
\hline & $V R 1$ & $V R 2$ & Total & $r$ & $V R 1$ & $V R 2$ & Total & $r$ \\
\hline Alpha Ventus & 19 & 15 & 34 & 2.83 & 17 & 15 & 32 & 2.67 \\
\hline Bard 1 & 40 & 39 & 79 & 0.99 & 40 & 39 & 79 & 0.99 \\
\hline Horns Rev 1 & 28 & 27 & 55 & 0.69 & 27 & 26 & 53 & 0.66 \\
\hline Lincs & 41 & 40 & 81 & 1.01 & 40 & 40 & 80 & 1 \\
\hline
\end{tabular}

In all cases, important wave height reductions were obtained, especially in Bard 1 with an average wave reduction between $17 \%$ and $19 \%$, thanks to the good interception of the incoming waves (Figure 11). These results were followed very closely by those obtained in Alpha Ventus (around 17\%) and Horns Rev 1 (between 15\% and 17\%), whereas the wave height reduction achieved at Lincs was smaller (around 13\%) since part of the farm remained unprotected against incoming waves from secondary directions due to its elongated shape (Figure 12). This fact was supported when the spatial variation in the wave height reduction was analysed, since in the case of Lincs the wave height reduction decreased from $40 \%$ in the wind turbines just behind the co-located WECs to $5 \%$ in the further turbines [103]. In fact, the most homogeneous reduction throughout the wind farm was achieved in the case of wind farms with geometry similar to a square and smaller spacing between wind turbines, such as Horns Rev 1. Moreover, this kind of farms would require fewer WECs to protect the whole farm from incoming waves. Another important factor in the results is the distance from the coast: Being closer to land is not a positive factor to implement co-located WECs, since it normally implies lower water depths and a milder sea climate, and consequently there is less available wave energy to be extracted by the WECs [103].
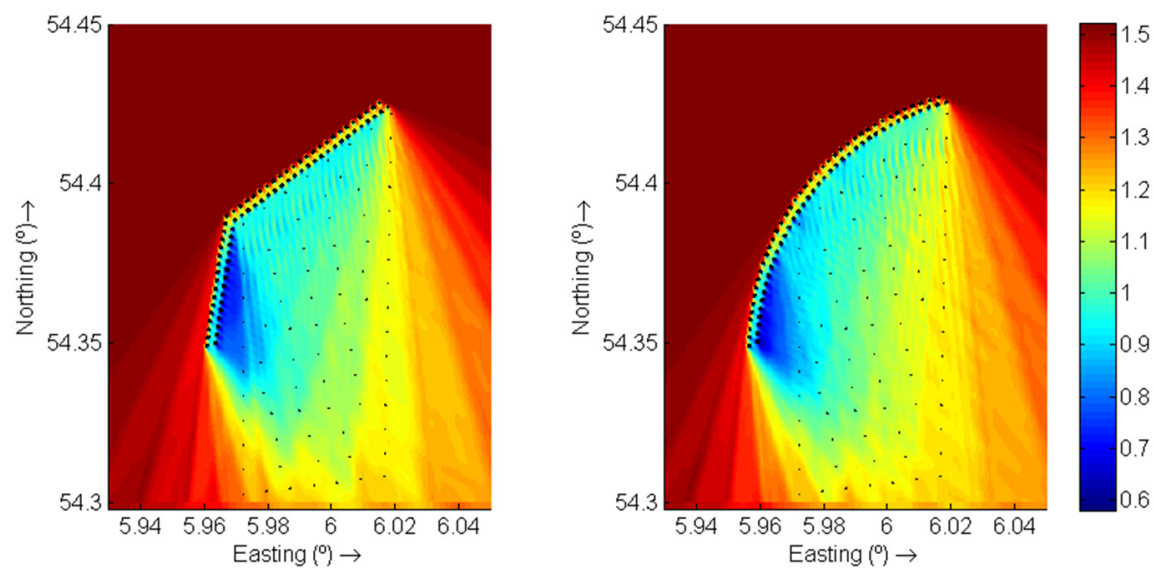

Figure 11. Wave height reduction due to co-located WECs at Bard 1 under a sea state with: $H_{s}=1.71 \mathrm{~m}, T_{p}=6.09 \mathrm{~s}$ and $\theta: 229.6^{\circ}$. The colour scale represents the significant wave weight, $H_{s}(\mathrm{~m})$. 

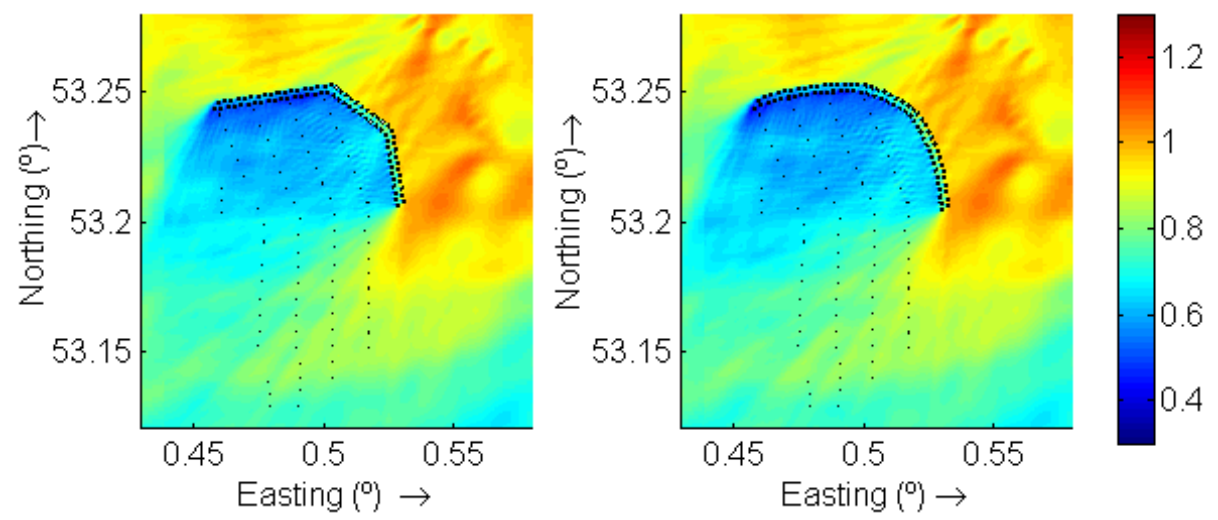

Figure 12. Wave height reduction obtained with co-located WECs at Lincs under a sea state with: $H_{s}=1.18 \mathrm{~m}, T_{p}=6.03 \mathrm{~s}$ and $\theta=60.16^{\circ}$. The colour scale represents the significant wave weight, $H_{s}(\mathrm{~m})$.

Although the combination of wave and wind energy farms presents better results in some cases than in others, the wave height reductions achieved bring in important improvements of the accessibility to the wind turbines for all the cases analysed (Table 9). In fact, the accessibility raised over $82 \%$ for two of the farms, which is the reference value to maintain a farm availability of above $90 \%$ [116]. In order to translate this increase of time accessibility into monetary terms, it could be considered an estimated cost (or lost earnings) of delayed repairs about $300 € / \mathrm{h}[122,123]$.

Table 9. Accessibility of the co-located farms and the increase $(\Delta)$ in comparison with the baseline scenarios. (Reprinted with permission from [103]. Copyright 2015 Elsevier Science Ltd.)

\begin{tabular}{cccc}
\hline Wind Farm & Layout & Accessibility (\%) & $\boldsymbol{\Delta} \mathbf{( \% )}$ \\
\hline \multirow{2}{*}{ Alpha Ventus } & in angle & 82.33 & 17.97 \\
& in arch & 82.19 & 17.83 \\
\hline \multirow{2}{*}{ Bard 1 } & in angle & 69.66 & 18.19 \\
& in arch & 69.04 & 17.46 \\
\hline \multirow{2}{*}{ Horns Rev 1 } & in angle & 70.89 & 15.56 \\
& in arch & 69.52 & 13.89 \\
\hline \multirow{2}{*}{ Lincs } & in angle & 81.30 & 8.85 \\
& in arch & 81.10 & 8.61 \\
\hline
\end{tabular}

Further, given that the wave height reduction within the wind farm decreases with the distance from the WECs barrier towards the periphery, it is interesting to analyse the accessibility to each individual wind turbine apart from the accessibility in the entire farm. The most remarkable thing is that a quite homogeneous level of accessibility is achieved within the entire farm, since around $50 \%$ of the wind turbines experienced an increase in the accessible timeframe of $20 \%$, and the remaining part an increase of at least $10 \%$, with the exception of Lincs where waves recover more quickly throughout the farm due to the soft climate and enlarged shape of the farm, and only the turbines of the first half of the farm experienced an increase in the accessibility over 10\% [103]. Indeed, in the case of Alpha Ventus, Bard and Horns Rev the ratio between the wave reduction in the most distant area and the average within the farm is over $60 \%$, whereas it is around $38 \%$ in Lincs. 
In order to translate the increase of time accessibility into monetary terms, it could be considered an estimated cost (or lost earnings) of delayed repairs about $300 € / \mathrm{h}[122,123]$. The aggregate failure rate per wind turbines is approximately five failures per year [124], and they occur particularly in the winter months due to the storm periods [125]. Therefore, it is likely that when these failures occur do sea conditions overtake the operational workboats limit, having to wait until the end of the storm - winter storm periods have an average duration between three and four days in the North Sea [126]. Thus, avoiding one of this downtime periods would involve cost savings around 25,000 $€$ per turbine.

\section{Conclusions}

The first aim of this paper was to present a general view of the economics of wave energy, a renewable which is still in its infancy but presents a large available resource. It was concluded that its offshore character - in most cases - along with the initial stage of development of the technology reduce the economic viability of wave energy, which may curb the development of this promising renewable technology. However, in a second part of the analysis, in which the learning curve factor was included in conjunction with the externalities, the levelised cost of wave energy was found to be closer to that of conventional energy resources. In fact, this assessment of the energy cost is a fairer analysis since includes all the factors involved throughout the life cycle of the energy installations.

The second purpose of this paper was to demonstrate that co-located wave and wind energy results in more convenient options than individual systems. In this sense, the paper gave a glimpse into the different synergies that can be realised by these combined systems, such as the reduced investment costs or smoothed power output, translating these benefits into monetary terms. Among the different synergies, this study focused on the reduction of operation and maintenance costs in a wind farm by increasing the accessibility to the wind turbines and, thus, reducing downtime periods. It was concluded that implementing co-located WECs in wind farms could raise significantly the accessibility to the wind turbines. In fact, increases by up to $18 \%$ were found, reaching high levels of availability even over $90 \%$. However, the shielding effect of the co-located WECs depends on the farm layout and characteristics of the wind farm. The best results were found for farm layouts with the minimum spacing between WECs, and protecting the wind farms not only from the predominant waves but also secondary directions. Wind farms with a disposition similar to a square required fewer co-located WECs than enlarged farms, and wind farms located in areas with less energetic wave climates benefited the least by the co-location of WECs.

Therefore, both offshore wind and wave energy would achieve mutual benefit throughout co-located farms. First, offshore wind farms would obtain enlarged weather windows for O \& M tasks, avoiding non-operational periods and the associated costs, while producing a smoother power output. Second, the inclusion of co-located WECs into wind farms could accelerate the development of wave energy technology, which may be expected to lead to reductions in the cost of wave energy based on the learning curve. 


\section{Acknowledgments}

This work was carried out in the framework of the Atlantic Power Cluster project (Atlantic Area Project No. 2011-1/151, ATLANTICPOWER), funded by the Atlantic Area Operational Transnational Programme as part of the European Regional and Development Fund (ERDF). Sharay Astariz has been supported by FPU grant 13/03821 of the Spanish Ministry of Education, Culture and Sport. The authors are grateful to: The Bundesamt für Seeschifffahrt und Hydrographie (BSH) of Germany for providing access to the bathymetrical and resource data from the FINO 1, 2 and 3 research platforms; to the UK's Centre for Environment, Fisheries and Aquaculture Science (CEFAS) for the resource data of the Dowsign buoy; to the Horns Rev wind farm for the resource data of the site; and to the European Marine Observation and Data Network (EMODnet) for the bathymetric data of the North Sea.

\section{Author Contributions}

Sharay Astariz implemented the main research, checked results, wrote the paper, and discussed the results. Gregorio Iglesias provided guidance and supervision and reviewed the paper. All authors read and approved the final manuscript.

\section{Conflicts of Interest}

The authors declare no conflict of interest.

\section{References}

1. Babarit, A.; Hals, J.; Muliawan, M.J.; Kurniawan, A.; Moan, T.; Krokstad, J. Numerical benchmarking study of a selection of wave energy converters. Renew. Energy 2012, 41, 44-63.

2. de O. Falcão, A.F. Modelling and control of oscillating-body wave energy converters with hydraulic power take-off and gas accumulator. Ocean Eng. 2007, 34, 2021-2032.

3. Marjani, A.E.; Ruiz, F.C.; Rodriguez, M.A.; Santos, M.T.P. Numerical modelling in wave energy conversion systems. Energy 2008, 33, 1246-1253.

4. Falcão, A.F.; Justino, P.A.P. OWC wave energy devices with air flow control. Ocean Eng. 1999, 26, 1275-1295.

5. Hayashi, T.; Hattori, M.; Kano, T.; Shirai, M. Hydraulic Research on the Closely Spaced Pile Breakwater. Coast. Eng. 1966, 50, 873-884.

6. Ramos, V.; Iglesias, G. Performance assessment of Tidal Stream Turbines: A parametric approach. Energy Convers. Manag. 2013, 69, 49-57.

7. Rourke, F.O.; Boyle, F.; Reynolds, A. Marine current energy devices: Current status and possible future applications in Ireland. Renew. Sustain. Energy Rev. 2010, 14, 1026-1036.

8. Tedd, J.; Peter Kofoed, J. Measurements of overtopping flow time series on the Wave Dragon, wave energy converter. Renew. Energy 2009, 34, 711-717.

9. Vicinanza, D.; Contestabile, P.; Quvang Harck Nørgaard, J.; Lykke Andersen, T. Innovative rubble mound breakwaters for overtopping wave energy conversion. Coast. Eng. 2014, 88, 154-170.

10. Setoguchi, T.; Takao, M. Current status of self rectifying air turbines for wave energy conversion. Energy Convers. Manag. 2006, 47, 2382-2396. 
11. Al-Habaibeh, A.; Su, D.; McCague, J.; Knight, A. An innovative approach for energy generation from waves. Energy Convers. Manag. 2010, 51, 1664-1668.

12. Allan, G.; Gilmartin, M.; McGregor, P.; Swales, K. Levelised costs of Wave and Tidal energy in the UK: Cost competitiveness and the importance of "banded" Renewables Obligation Certificates. Energy Policy 2011, 39, 23-39.

13. Allan, G.J.; Bryden, I.; McGregor, P.G.; Stallard, T.; Kim Swales, J.; Turner, K.; Wallace, R. Concurrent and legacy economic and environmental impacts from establishing a marine energy sector in Scotland. Energy Policy 2008, 36, 2734-2753.

14. Dalton, G.J.; Alcorn, R.; Lewis, T. A 10 year installation program for wave energy in Ireland: A case study sensitivity analysis on financial returns. Renew. Energy 2012, 40, 80-89.

15. Deane, J.P.; Dalton, G.; Ó Gallachóir, B.P. Modelling the economic impacts of 500MW of wave power in Ireland. Energy Policy 2012, 45, 614-627.

16. Prässler, T.; Schaechtele, J. Comparison of the financial attractiveness among prospective offshore wind parks in selected European countries. Energy Policy 2012, 45, 86-101.

17. Abanades, J.; Greaves, D.; Iglesias, G. Wave farm impact on the beach profile: A case study. Coast. Eng. 2014, 86, 36-44.

18. Carballo, R.; Iglesias, G. Wave farm impact based on realistic wave-WEC interaction. Energy 2013, 51, 216-229.

19. Frid, C.; Andonegi, E.; Depestele, J.; Judd, A.; Rihan, D.; Rogers, S.I.; Kenchington, E. The environmental interactions of tidal and wave energy generation devices. Environ. Impact Assess. Rev. 2012, 32, 133-139.

20. Iglesias, G.; Carballo, R. Wave farm impact: The role of farm-to-coast distance. Renew. Energy 2014, 69, 375-385.

21. Kadiri, M.; Ahmadian, R.; Bockelmann-Evans, B.; Rauen, W.; Falconer, R. A review of the potential water quality impacts of tidal renewable energy systems. Renew. Sustain. Energy Rev. 2012, 16, 329-341.

22. Margheritini, L.; Hansen, A.M.; Frigaard, P. A method for EIA scoping of wave energy converters-Based on classification of the used technology. Environ. Impact Assess. Rev. 2012, $32,33-44$.

23. Neill, S.P.; Jordan, J.R.; Couch, S.J. Impact of tidal energy converter (TEC) arrays on the dynamics of headland sand banks. Renew. Energy 2012, 37, 387-397.

24. Neill, S.P.; Litt, E.J.; Couch, S.J.; Davies, A.G. The impact of tidal stream turbines on large-scale sediment dynamics. Renew. Energy 2009, 34, 2803-2812.

25. Palha, A.; Mendes, L.; Fortes, C.J.; Brito-Melo, A.; Sarmento, A. The impact of wave energy farms in the shoreline wave climate: Portuguese pilot zone case study using Pelamis energy wave devices. Renew. Energy 2010, 35, 62-77.

26. Shields, M.A.; Woolf, D.K.; Grist, E.P.M.; Kerr, S.A.; Jackson, A.C.; Harris, R.E.; Bell, M.C.; Beharie, R.; Want, A.; Osalusi, E.; et al. Marine renewable energy: The ecological implications of altering the hydrodynamics of the marine environment. Ocean Coast. Manag. 2011, 54, 2-9.

27. Smith, H.C.M.; Pearce, C.; Millar, D.L. Further analysis of change in nearshore wave climate due to an offshore wave farm: An enhanced case study for the Wave Hub site. Renew. Energy 2012, 40, 51-64. 
28. Moccia, J.; Arapogianni, A. Pure Power. Wind Energy Targets for 2020 and 2030; European Wind Energy Association: Brussels, Belgium, 2011.

29. Ramos, V.; Iglesias, G. Wind Power Viability on a Small Island. Int. J. Green Energy 2014, 11, 741-760.

30. Veigas, M.; Iglesias, G. Potentials of a hybrid offshore farm for the island of Fuerteventura. Energy Convers. Manag. 2014, 86, 300-308.

31. Veigas, M.; Carballo, R.; Iglesias, G. Wave and offshore wind energy on an island. Energy Sustain. Dev. 2014, 22, 57-65.

32. Veigas, M.; Iglesias, G. Wave and offshore wind potential for the island of Tenerife. Energy Convers. Manag. 2013, 76, 738-745.

33. Carballo, R.; Iglesias, G. A methodology to determine the power performance of wave energy converters at a particular coastal location. Energy Convers. Manag. 2012, 61, 8-18.

34. Falnes, J.; Løvseth, J. Ocean wave energy. Energy Policy 1991, 19, 768-775.

35. Iglesias, G.; Carballo, R. Offshore and inshore wave energy assessment: Asturias (N Spain). Energy 2010, 35, 1964-1972.

36. Iglesias, G.; Carballo, R. Wave energy resource in the Estaca de Bares area (Spain). Renew. Energy 2010, 35, 1574-1584.

37. Iglesias, G.; Carballo, R. Wave power for La Isla Bonita. Energy 2010, 35, 5013-5021.

38. Iglesias, G.; Carballo, R. Wave resource in El Hierro-An island towards energy self-sufficiency. Renew. Energy 2011, 36, 689-698.

39. Lenee-Bluhm, P.; Paasch, R.; Özkan-Haller, H.T. Characterizing the wave energy resource of the US Pacific Northwest. Renew. Energy 2011, 36, 2106-2119.

40. Cruz, J.G.M.; Barstow, S.; Mollison, D. Green Energy and Technology, Ocean Wave Energy. Springer Science, Business Media: New York, NY, USA, 2008; ISBN:978-3-540-74895-3.

41. ECOR. Members of the Engineering Committee on Oceanic Resources (ECOR) Working Group on Wave Energy Conversion. In Elsevier Ocean Engineering Series; Bhattacharyya, R., McCormick, M.E., Eds.; Elsevier: London, UK, 2003; Volume 6, p. 7.

42. Fernandez, H.; Iglesias, G.; Carballo, R.; Castro, A.; Fraguela, J.A.; Taveira-Pinto, F.; Sanchez, M. The new wave energy converter WaveCat: Concept and laboratory tests. Mar. Struct. 2012, 29, $58-70$.

43. Isaacson, M. Waves Forces on Compound Cylinders. In Proceedings of the Civil Engineering in the Oceans IV, Auckland, New Zealand, 8-12 December 1986; ASCE: San Francisco, CA, USA, 1986; Volume 1.

44. López, I.; Iglesias, G. Efficiency of OWC wave energy converters: A virtual laboratory. Appl. Ocean Res. 2014, 44, 63-70.

45. Paixão Conde, J.M.; Gato, L.M.C. Numerical study of the air-flow in an oscillating water column wave energy converter. Renew. Energy 2008, 33, 2637-2644.

46. Vicinanza, D.; Nørgaard, J.; Contestabile, P.; Andersen, T.L. Wave loadings acting on Overtopping Breakwater for Energy Conversion. J. Coast. Res. 2013, 65, 1669-1674.

47. Vicinanza, D.; Ciardulli, F.; Buccino, M.; Calabrese, M.; Kofoed, J. Wave loadings acting on an innovative breakwaters for energy production. J. Coast. Res. 2011, 64, 608-612. 
48. Buccino, M.; Banfi, D.; Vicinanza, D.; Calabrese, M.; Giudice, G.D.; Carravetta, A. Non Breaking Wave Forces at the Front Face of Seawave Slotcone Generators. Energies 2012, 5, 4997-4803.

49. Astariz, S.; Iglesias, G. The economics of wave energy: A review. Renew. Sustain. Energy Rev. 2015, 45, 397-408.

50. Azzellino, A.; Ferrante, V.; Kofoed, J.P.; Lanfredi, C.; Vicinanza, D. Optimal siting of offshore wind-power combined with wave energy through a marine spatial planning approach. Int. J. Mar. Energy 2013, 3-4, e11-e25.

51. Pérez-Collazo, C.; Greaves, D.; Iglesias, G. A review of combined wave and offshore wind energy. Renew. Sustain. Energy Rev. 2015, 42, 141-153.

52. Power-Technology.com Green Ocean Energy Wave Trader, United Kingdom. Available online: http://www.power-technology.com/projects/greenoceanenergywav/ (accessed on 9 April 2014).

53. Pérez-Collazo, C.; Jakobsen, M.M.; Buckland, H.; Fernández-Chozas, J. Synergies for a Wave-Wind Energy Concept; EWEA: Frankfurt, Germany, 2013.

54. Fusco, F.; Nolan, G.; Ringwood, J.V. Variability reduction through optimal combination of wind/wave resources - An Irish case study. Energy 2010, 35, 314-325.

55. Astariz, S.; Perez-Collazo, C.; Abanades, J.; Iglesias, G. Co-located wind-wave farm synergies (Operation \& Maintenance): A case study. Energy Convers. Manag. 2015, 91, 63-75.

56. Perez-Collazo, C.; Astariz, S.; Abanades, J.; Greaves, D.; Iglesias, G. Co-located wave-wind farms: A preliminary approach to the shadow effect. In Proceedings of the International Conference on Ocean Energy (ICOE), Halifax, NC, Canada, 4-6 November 2014.

57. Falcão, A.F.D.O. Wave energy utilization: A review of the technologies. Renew. Sustain. Energy Rev. 2010, 14, 899-918.

58. Astariz, S.; Iglesias, G. Wave energy vs. other energy sources: A reassessment of the economics. Int. J. Green Energy 2014, in press.

59. Previsic, M. System Level Design, Performance, and Costs of California Pelamis Wave Power Plant; EPRI: San Francisco, CA, USA, 2004. Available online: http://oceanenergy.epri. com/attachmentes/wave/reports/006_San_Francisco_Pelamis_Conceptual_Design_12-11-04.pdf (accessed on 1 November 2013).

60. Castaño, M. Sistema de Monitorización y Supervisión de Una Boya Para Generación de Energía Undimotriz; Universidad Politécnica de Cataluña: Barcelona, Spain, 2011. (In Spanish)

61. Li, Y.; Lence, B.J.; Calisal, S.M. An integrated model for estimating energy cost of a tidal current turbine farm. Energy Convers. Manag. 2011, 52, 1677-1687.

62. BWEA (British Wind Energy Association). Marine Renewable Energy-State of the Industry Report; BWEA: London, UK, 2009. Available online: http://www.bwea.com/pdf/marine/ Marine_report_enteclogo.pdf(accessed on 1 May 2015).

63. Carbon Trust. Future Marine Energy Results of the Marine Energy Challenge: Cost Competitiveness and Growth of Wave and Tidal Stream Energy; Carbon Trust: London, UK, 2006.

64. Santos, C.C. Estudio de plantas de producción de energías renovables con aprovechamiento de la energía del mar. Ph.D. Thesis, Department of Electricity, Universidad Carlos III de Madrid, 2011. (In Spanish) 
65. Dalton, G.; Alcorn, R.; Lewis, T. Operational Expenditure Costs for Wave Energy Projects, O/M, Insurance and Site Rent. In Proceedings of the 3rd International Conference on Ocean Energy (ICOE), Bilbao, Spain, 6-8 October 2010.

66. VicinayCemvisa. Available online: http://www.vicinaycemvisa.com (accessed on 10 February 2015).

67. Couñago, B.; Barturen, R. Estudio técnico-ficanciero sobre la construcción de un parque eólico marino flotante en el litoral español. Ing. Nav. 2010, 886, 85-105. (In Spanish)

68. O’Connor, M.; Lewis, T.; Dalton, G. Operational expenditure costs for wave energy projects and impacts on financial returns. Renew. Energy 2013, 50, 1119-1131.

69. Farley, F.J.M. Capture Width for Arrays of Wave Energy Converters. Energy and Climate Change Division, University of Southampton. Available online: http://www,iwwwfb.org/ Abstracts/iwwwfb28/iwwwfb28_18.pdf (accessed on 1 December 2012).

70. Garnaud, X.; Mei, C.C. Bragg scattering and wave-power extraction by an array of small buoys. Proc. R. Soc. 2012, 466, 79-106.

71. Anderson, C. Pelamis WEC-Main Body Structural Design and Materials Selection; Ocean Power Delivery Ltd.: Edinburgh, UK, 2003. Available online: http://webarchive.nationalarchives. gov.uk/tna/ (accessed on 1 September 2010).

72. Medel, S. Study of the Introduction of Wave and Tidal Technologies as Small Ways of Electricity Generation; University of Chile: Santiago, RM, Chile, 2010.

73. Sorensen, H. WaveDragon-from the $20 \mathrm{~kW}$ to the $7 \mathrm{MW}$ Prototype Device. In Proceedings of the EU Contactors' Meeting, Bremerhaven, Germany, 25 October 2006.

74. Weinstein, A. AquaBuOY in Portugal; AquaEnergy Group Ltd. Finavera Renewables. Available online: http://www.ec.europa.eu/research/energy/pdf/gp/gp_events/ocean_energy/145_ aquabuoy_demo_plant_en.pdf (accessed on 1 May 2015).

75. Batten, W.; Bahaj, A.B. An Assessment of Growth Scenarios and Implications for Ocean Energy Industries in Europe; Report for CA-OE, Project no. 502701, WP5 Suatainable Energy Research Group, School of Civil Engineering and the Environment, University of Southampton: Southampton, UK, 2006.

76. Hoffmann, W. PV solar electricity industry: Market growth and perspective. Sol. Energy Mater. Sol. Cells 2006, 90, 3285-3311.

77. Junginger, M.; Faaij, A.; Turkenburg, W.C. Global experience curves for wind farms. Energy Policy 2005, 33, 133-150.

78. Junginger, H.M.; Turkenburg, W.C.; Faaij, A. Cost reduction prospects for offshore wind farms. Wind Eng. 2004, 28, 22, doi:10.1260/0309524041210847.

79. European Commission. ExternE: Externalities of Energy. Methodology 2005 Update. Available online: http://ec.europa.eu/research/energy/pdf/kina_en.pdf (accessed on 1 January 2015).

80. European Commission. Research results on Socio-Environmental Damages Due to Electricity and Transport. External Costs. Available online: http://www.externe.info/externe_2006/ externpr.pdf (accessed on 21 December 2006).

81. DTI Energy Group. Wave and Tidal-stream Energy Demonstration Scheme. Available online: http://webarchive.nationalarchives.gov.uk/20060802134639/dti.gov.uk/files/file27061.pdf (accessed on 1 October 2005). 
82. IDAE. Factores de conversión a energía primaria y facto de emisión de $\mathrm{CO}_{2}$ para carburantes, usos térmicos y electricidad. 2010. (In Spanish). Available online: http:/www.minetur.gob.es/ energia/desarrollo/EficienciaEnergetica/RITE/propuestas/Documents/2014_03_03_Factores_de_ emision_CO2_y_Factores_de_paso_Efinal_Eprimaria_V.pdf (accessed on 1 June 2012).

83. IDAE. Impacto económico de las energías renovables en el sistema productivo español. Estudio técnico, PER 2011-2020. 2011 (In Spanish). Available online: http:/www.idae.es/uploads/ documentos/documentos_Datos_Consumos_Energeticos_Mensuales._Ano_2009_9b4829f2.pdf (accessed on 1 June 2012).

84. Gaterell, M.; McEvoy, M. The impact of energy externalities on the cost effectiveness of energy efficiency measures applied to dwellings. Energy Build. 2005, 37, 1017-1027.

85. Galetovic, A.; Muñoz, C. Wind, coal, and the cost of environmental externalities. Energy Policy 2013, 62, 1385-1391.

86. Kitson, L.; Wooders, P.; Moerenhout, T. Subsidies and external costs in electric power generation: A comparative review of estimates. Available online: https:/www.iisd.org/gsi/sites/ default/files/power_gen_subsides.pdf (accessed on 1 February 2014).

87. Stoutenburg, E.D.; Jenkins, N.; Jacobson, M.Z. Power output variations of co-located offshore wind turbines and wave energy converters in California. Renew. Energy 2010, 35, 2781-2791.

88. Pérez-Collazo, C.; Astariz, S.; Abanades, J.; Greaves, D.; Iglesias, G. Co-located Wave and Offshore Wind Farms. A preliminary Case Study of a Hybrid Array. In Proceedings of the 22nd International Conference on Computers in Education (ICCE 2014), Nara, Japan, 30 November-4 December 2014.

89. Borg, M.; Collu, M.; Brennan, F.P. Use of a Wave Energy Converter as a Motion Suppression Device for Floating Wind Turbines. Energy Procedia 2013, 35, 223-233.

90. Farrugia, R.; Sant, T.; Micallef, D. Investigating the aerodynamic performance of a model offshore floating wind turbine. Renew. Energy 2014, 70, 24-30.

91. Muliawan, M.J.; Karimirad, M.; Moan, T. Dynamic response and power performance of a combined Spar-type floating wind turbine and coaxial floating wave energy converter. Renew. Energy 2013, 50, 47-57.

92. Caballero, F.; Sauma, E.; Yanine, F. Business optimal design of a grid-connected hybrid PV (photovoltaic)-wind energy system without energy storage for an Easter Island's block. Energy 2013, 61, 248-261.

93. Lund, H. Large-scale integration of optimal combinations of PV, wind and wave power into the electricity supply. Renew. Energy 2006, 31, 503-515.

94. Astariz, S.; Iglesias, G. Co-located wave-wind farms: Economic assessment as a function of layout. Renew. Energy 2015, 83, 837-849.

95. Variability of UK Marine Resources. Environmental Change Institute (ECI): Oxford, UK; Carbon Trust: London, UK. Available online: http://www.marinerenewables.ca/wp-content/uploads/ 2012/11/Variability-of-UK-marine-resources.pdf (accessed on 1 May 2015).

96. Diversified Renewable Energy Sources-An Assessment of an Integrated Wind, Wave and Tidal Stream Electricity Generating System in the UK, and the Reliability of Wave Power Forecasting; Environmental Change Institute (ECI): Oxford, UK; Carbon Trust: London, UK, 2006. Available online: https://www.carbontrust.com/media/174021/diversifiedrenewableenergyresources.pdf (accessed on 1 December 2014). 
97. Soerensen, H.C.; Nielsen, K.; Steenstrup, P.; Friis-Madsen, E.; Wigant, L. Bølgekraftanlaeg ved Horns Rev-Screening (Wave energy deployment at Horns Rev Wind Farm); PSO project 2004:5705; Bølgekraftanlæg ved Horns Rev: Copenhagen, Denmark, 2004.

98. Chozas, J.F.; Jensen, N.H.; Sørensen, H. Economic Benefit of Combining Wave and Wind Power Productions in Day-Ahead Electricity Markets. In Proceedings of the 4th International Conference on Ocean Energy (ICOE), Dublin, Ireland, 17-19 October 2012.

99. Chozas, J.F.; Kofoed, J.P.; Sørensen, H.C. Predictability and Variability of Wave and Wind and Wind Forecasting and Diversified Energy Systems in the Danish North Sea; DCE Technical Reports No. 156; Department of Civil Engineering, Aalborg University: Aalborg, Denmark, 2013.

100. Bierbooms, W.A.A.M.; Bussel, G.J.W.V. The Impact of Different Means of Transport on the Operation and Maintenance Strategy for Offshore Wind Farms; Section Wind Energy, Faculty Civil Engineering and Geosciences, Delft University of Technology: Delft, The Netherlands, 2002.

101. Daubney, K. Getting technicians to far-shore wind farms. Available online: http://www. windpoweroffshore.com/article/1214096/getting-technicians-far-shore-wind-farms (accessed on 15 July 2013).

102. Scottish Enterprise. Innovation in Offshore Wind. Installation, Operation \& Maintenance. Opportunities in energy. Available online: http:/www.scottish-enterprise.com/ /media/SE/Resources/ Documents/MNO/OW\%20Innovation\%20-\%20IOM\%20v1.0.pdf (accessed on 1 December 2012).

103. Astariz, S.; Abanades, J.; Perez-Collazo, C.; Iglesias, G. Improving wind farm accessibility for operation \& maintenance through a co-located wave farm: Influence of layout and wave climate. Energy Convers. Manag. 2015, 95, 229-241.

104. Astariz, S.; Perez-Collazo, C.; Abanades, J.; Iglesias, G. Towards the optimal design of a co-located wind-wave farm. Energy 2015, 84, 15-24.

105. Ponce de Leon, S.; Bettencourt, J.H.; Kjerstad, N. Simulation of Irregular Waves in an Offshore Wind Farm with a Spectral Wave Model. Cont. Shelf Res. 2011, 31, 1541-1557.

106. ETSU. Potential Effects of Offshore Wind Developments on Coastal Processes. ETSU W/35/00596/00/REP. Available online: http://www.offshorewindenergy.org/reports/report 002.pdf (accessed on 1 September 2002).

107. Millar, D.L.; Smith, H.C. M.; Reeve, D.E. Modelling analysis of the sensitivity of shoreline change to a wave farm. Ocean Eng. 2007, 34, 884-901.

108. Veigas, M.; Ramos, V.; Iglesias, G. A wave farm for an island: Detailed effects on the nearshore wave climate. Energy 2014, 69, 801-812.

109. FINO1. Fino 1 Location. Forschungsplattformen in Nord- und Ostsee Nr.1. 2012. Available online: http://www.fino1.de/en/location-sea-floor-waves-wind (accessed on 16 July 2015).

110. Fraunhofer Institute for Wind Energy and Energy System Technology IWES. Wind Energy Report Germany 2010; Fraunhofer IWES: Kassel, Germany, 2010. Available online: http://windmonitor. iwes.fraunhofer.de/opencms/export/sites/windmotor/img/Wind_energy_report_2010.pdf (accessed on 1 February 2015).

111. Bard offshore wind farm fact sheet. Available online: http://www.4coffshore.com/ windfarms/bard-offshore-1-germany-de23.html (accessed on 13 June 2014).

112. Bard offshore wind farm. Available online: http://www.lorc.dk/offshore-wind-farms-map/ bard-offshore-1 (accessed on 13 June 2014). 
113. Elsam Essential Energy. Horns Rev offshore wind farm. Ground-breaking wind power plant in the North Sea. Available online: http://www.mumm.ac.be/Common/Windmills/SPE/Bijlage/ $1 \% 20 \% 20$ Horns_Rev_brochure.pdf (accessed on 16 July 2015).

114. Centrica Energy. LINCS Offshore Wind Farm Decommissioning Plan; On behalf Lincs Wind Farm Limited. DONG Energy: Fredericia, Denmark, 2010. Available online: https://www.centrica.com/files/pdf/centrica_energy/lincs_offshore_wind_farm_decomissioning plan.pdf (accessed on 20 November 2014).

115. Lincs offshore wind farm. Available online: http://www.4coffshore.com/windfarms/lincs-unitedkingdom-uk13.htm (accessed on 13 June 2014).

116. Van Bussel, G.J.W.; Bierbooms, W.A.A.M. The DOWEC Offshore Reference Windfarm: Analysis of transportation for operation and maintenance. Wind Eng. 2003, 27, 381-388.

117. Van Bussel, G.J.W.; Zaaijer, M.B. Reliability, Availability and Maintenance aspects of large-scale offshore wind farms, a concepts study. In Proceedings of the Offshore wind energy special topic conference, Brussels, Belgium, 10-12 December 2001.

118. Perveen, R.; Kishor, N.; Mohanty, S.R. Off-shore wind farm development: Present status and challenges. Renew. Sustain. Energy Rev. 2014, 29, 780-792.

119. Scheu, M.; Matha, D.; Hofmann, M.; Muskulus, M. Maintenance Strategies for Large Offshore Wind Farms. Energy Procedia 2012, 24, 281-288.

120. Makridis, C. Offshore wind power resource availability and prospects: A global approach. Environ. Sci. Policy 2013, 33, 28-40.

121. Iglesias, G.; Fernández, H.; Carballo, R.; Castro, A.; Taveira-Pinto, F. The WaveCat ${ }^{\complement}$-Development of a new Wave Energy Converter. In Proceedings of the World Renewable Energy Congress 2011, Linkoping, Sweden, 8-13 May 2011.

122. Rademakers, L.W.M.M.; Braam, H.; Obdam, T.S.; Frohböse, P.; Kruse, N. Tools for estimating operation and maintenance costs of offshore wind farms: State of the Art. In Proceedings of the EWEC 2008, Brussels, Belgium, 31 March-3 April 2008.

123. Dinwoodie, I.; McMillan, D. Sensitivity of Offshore Wind Turbine Operation \& Maintenance Costs to Operational Parameters. In Proceedings of the 42nd ESReDA Seminar. Risk and Reliability for Wind Energy and other Renewable Sources, Glasgow, UK, 14-16 May 2012.

124. Besnard, F. On Maintenance Optimization for Offshore Wind Farms. Available online: http://www.elforsk.se/Global/Vindforsk/Rapporter\%20VFIII/V_327_Besnard_Phd_thesis.pdf (accessed on 1 September 2013).

125. The Crown Estate. Jack-up Vessel Optimisation. Available online: http://www.thecrownestate. co.uk/media/451536/ei-km-in-om-construction-072014-jack-up-vessel-optimisation.pdf (accessed on 1 September 2014).

126. Woth, K.; Weisse, R.; Storch, H.V. Climate change and North Sea storm surge extremes: An ensemble study of storm surge extremes expected in a changed climate projected by four different regional climate models. Ocean Dyn. 2006, 56, 3-15.

(C) 2015 by the authors; licensee MDPI, Basel, Switzerland. This article is an open access article distributed under the terms and conditions of the Creative Commons Attribution license (http://creativecommons.org/licenses/by/4.0/). 